\title{
PKM Peningkatan Kemampuan Berbicara pada Karang Taruna RT 007 RW 05 Kelurahan Tanjung Barat, Jagakarsa Jakarta Selatan
}

\author{
Doni Anggoro Ari Santoso, Agung Prasetyo \\ Universitas Indraprasta PGRI, Jakarta, Indonesia \\ don.okba@gmail.com
}

\begin{abstract}
Abstrak: Kegiatan pengabdian ini dilaksanakan untuk karang taruna di lingkungan RT 007 RW 005 Tanjung Barat Jagakarsa Jakarta Selatan. Tujuan dari diadakannya kegiatan pengabdian masyarakat ini adalah untuk menambah pengetahuan pemuda khususnya karang taruna dalam meningkatkan keterampilan berbicara. Karena di dalam organisasi atau kegiatan yang dilakukan bersama-sama diperlukan komunikasi yang baik supaya yang disampaikan dapat dengan mudah dipahami oleh audiensi. Di dalam berkomunikasi juga diperlukan pemilihan kata yang tepat agar kalimat dapat tersusun dengan baik dan dapat disampaikan dengan baik dan mudah dipahami. Hal inilah yang dirasa masih banyak terjadi kekurangan di karang taruna RT 007 RW 05, untuk itu diperlukan penambahan wawasan tenteng bagaimana meningkatkan keterampilan berbicara dengan orang lain.
\end{abstract}

Kata Kunci: PKM, kemampuan berbicara, Karang Taruna

Abstract: This activity is carried out for youth groups of RT 007 RW 005 Tanjung Barat Jagakarsa, South Jakarta. The purpose of this community service activity is to increase the knowledge of youth in improving speaking skills. Good communications are needed by the youth in carrying organizational activities so the message can be easily understood by the audience. In communicating, it is also necessary to choose the right words so that sentences can be well structured and can be conveyed properly and easily understood. The writers felt that there are still many shortcomings in the youth organization of RT 007 RW 05, and it is necessary to add insight on how to improve speaking skills with other people.

Keywords: PKM, speaking skill, Youth Organization

\section{Pendahuluan}

Berkomunikasi di depan publik bagi seorang remaja dan pemuda bukanlah hal yang mudah. Tidak sedikit kaum muda yang tidak berkesempatan belajar cara berkomunikasi yang baik di depan publik. Beberapa pemuda masih salah tingkah dan belum mampu menyampaikan pemikirannya lewat komunikasi verbal. Terkadang mereka harus member sambutan sebagai ketua panitia dalam kegiatan kepemudaan, sebagai MC (Master of Ceremony), dalam memimpin musyawarah/rapat kepemudaan, atau dalam acara publik lainnya. Dalam ilmu retorika dibahas secara detail tata cara berbicara di depan publik dengan seni tertentu sehingga dapat memukau audiensi. Tidak sedikit hubungan yang sudah dirintis dengan susah payah menjadi rusak karena kesalahan dalam berkomunikasi.

Kemampuan berkomunikasi seperti tersebut di atas dapat dipelajari dalam ilmu retorika. Ia juga merupakan seni ilmu pengetahuan mengenai komunikasi lisan yang efektif dengan para pendengarnya. Hal ini dimaksudkan untuk mempengaruhi, mengajak, mendidik, mengubah opini, memberikan penjelasan kepada masyarakat di tempat tertentu (Lukiati Komala. 2009: 197). Pada dasarnya retorika dapat dipelajari oleh siapapun terlebih lagi bagi para pembicara publik. Ini adalah bagian penting bagi siapapun untuk dapat memperoleh perhatian besar dari para audiens. Sebagai sebuah upaya dalam berkomunikasi seyogyanya perlu senantiasa 
dievaluasi sehingga kualitasnya akan semakin baik.

Membangun suatu kerangka rujukan dalam menghadapi kondisi sosial masyarakat seharihari adalah dengan berkomunikasi, salah satunya adalah dengan menggunakan bahasa lisan. Komunikasi pula yang memungkinkan individu maupun kelompok mempelajari dan menerapkan strategi-strategi yang adaptip untuk mengatasi situasi-situasi problematik yang dimasuki. Tanpa melibatkan diri dalam komunikasi seseorang tidak akan tahu bagaimana makan, minum, berbicara dan memperlakukan manusia lain secara beradab, karena cara-cara berperilaku tersebut harus dipelajari lewat pengasuhan keluarga dan pergaulan dengan orang lain (Deddy Mulyana, 2005: 5-6).

Komunikasi merupakan bagian penting dari kehidupan manusia. Sejak dilahirkan, manusia sudah berkomunikasi dengan lingkungan sekitarnya. Untuk menjalin rasa kemanusiaan yang akrab dan harmonis maka diperlukan komunikasi yang efektif sehingga dapat memberikan manfaat dalam kehidupan manusia sepanjang sejarah. Islam sebagai jalan hidup menjelaskan tata nilai yang dapat diterapkan dalam berbagai segi kehidupan. Dalam komunikasi pun Alquran memperkenalkan cara sekaligus nilai dalam membangun komunikasi dengan berbagai pihak.

Karang Taruna adalah bagian dari masyarakat yang selalu mengadakan kegiatan sosial maupun kegiatan keagamaan. Bahkan karang taruna juga menjadi sekolah kedua selain sekolah formal yang dapat diikuti oleh anggota masyarakat. Berbagai kegiatan diselenggarakan oleh karang taruna yang tersebar di seluruh Indonesia. Karang Taruna RT. 007 RW. 05 Kel. Tanjung Barat adalah Karang Taruna yang cukup aktif mengadakan berbagai kegiatan sosial dan keagamaan. Karang taruna mengadakan kerja sama dengan berbagai pihak untuk mengembangkan kemampuan para remaja dan pemuda khususnya dalam kemampuan berbicara di depan publik.

Para peserta dari karang taruna dan jamaah pemuda masjid sering bersama dalam melakukan kegiatan. Meskipun demikian tidak sedikit dari mereka yang tidak tahu tentang teknik berkomunikasi yang baik. Termasuk dalam memilih kata yang tepat dalam berbahasa lisan sehari-hari khususnya dalam berbicara di depan umum. Akibatnya salah paham kerap kali terjadi yang menjadikan hubungan kerjasama di antara mereka kurang kondusif. Hal inilah yang mendorong penulis untuk memberikan penyuluhan terkait bahasa lisan dalam penggunaannya sehari hari. Berdasarkan persoalan di atas maka kegiatan penyuluhan ini bertemakan Penerapan ilmu retorika dalam khutbah, kultum, dan ceramah: PKM Peningkatan Kemampuan Berbicara pada Karang Taruna RT 007 RW 05 Kelurahan Tanjung Barat, Jagakarsa, Jakarta Selatan.

Komunikasi diperlukan untuk mengatur tata krama pergaulan antar manusia, apakah itu seorang pengusaha, dokter, guru, karyawan atau politisi sebab berkomunikasi dengan baik akan memberi pengaruh langsung pada struktur keseimbangan seseorang dalam bermasyarakat. Berkomunikasi (William, 1978:28) yang baik akan memungkinkan individu maupun kelompok membangun suatu kerangka rujukan dan menggunakannya sebagai panduan untuk situasi apapun yang dihadapi. Pendek kata, keberhasilan atau kegagalan seseorang dalam mencapai sesuatu yang diinginkan, termasuk karier dan rezekinya ditentukan oleh kemampuannya berkomunikasi.

Proses komunikasi dangat dipengaruhi oleh penggunaan bahasa yang baik dan benar. 
Anggota jamaah majelis taklim tidak dapat menyampaikan perasaan, pikiran, dan gagasan secara efektif apabila tidak menguasai sarananya dengan baik dan santun. Menurut Baryadi, (2003:15) "Kesantunan berbahasa adalah tata cara, adat, atau kebiasaan yang berlaku dalam masyarakat".

Dalam kehidupan sehari-hari, masyarakat selalu menjadi tempat untuk berbagai keperluan. Dari satu individu terhadap individu yang lain, dari satu kelompok terhadap kelompok yang lainnya. Begitu pula karang taruna sebagai kelompok dalam masyarakat. Umumnya masalah yang muncul adalah anggota tidak mengetahui apakah komunikasi yang digunakan selama ini sudah memenuhi kriteria sebagai komunikasi yang baik. Abdimas dalam bentuk penyuluhan ini lebih memfokuskan pada komunikasi lisan.

\section{Metode}

Sasaran kegiatan pengabdian ini adalah pemuda karang taruna dan remaja masjid RT.007 RW. 05 Kel. Tanjung Barat. Diharapkan dengan pelatihan ini seluruh peserta dapat menerapkan komunikasi verbal yang baik dalam berbicara di depan publik.

Kegiatan pengabdian masyarakat ini dilakukan dengan mendatangi lokasi kegiatan di Sekretariat RT. 007 RW. 05 Kel. Tanjung Barat, Jagakarsa, Jakarta Selatan yang kemudian diberi materi tentang komunikasi verbal teknik dan praktiknya di depan publik.

Kegiatan ini menggunakan konsep pelatihan. Dengan demikian diharapkan peserta dapat aktif bertanya, berdiskusi, berkreasi, serta berlatih menggunakan teknik komunikasi verbal yang efektif dan efisien.

Peserta kegiatan ini adalah pemuda karang taruna dan remaja masjid RT. 007 RW. 05, Kel. Tanjung Barat, Jagakarsa, Jakarta Selatan.

Pembimbing dalam kegiatan ini adalah dosen yang berada dalam program studi pendidikan bahasa Inggris dan mampu pada bidangnya, berikut tabel mengenai pembimbing kegiatan.

\section{Tabel Pembimbing/Pemateri Kegiatan}

\begin{tabular}{|c|c|}
\hline Doni Anggoro Ari Santoso & $\begin{array}{c}\text { Merupakan dosen pengampu mata kuliah Speaking, } \\
\text { Metode Penelitian, Seminar on Language Teaching, } \\
\text { dan Teaching English as Foreign Language pada } \\
\text { Universitas Indraprasta PGRI. }\end{array}$ \\
\hline Agung Prasetyo & $\begin{array}{c}\text { Merupakan dosen pengampu mata kuliah Listening, } \\
\text { Speaking, dan Komputer Terapan pada Universitas } \\
\text { Indraprasta PGRI. }\end{array}$ \\
\hline
\end{tabular}

\section{Hasil dan Pembahasan}

Kegiatan pengabdian masyarakat ini dilaksanakan sesuai dengan langkah-langkah kegiatan secara berurutan yang telah disusun dlam tabel 3 berikut ini: 
Tabel Skema Pelaksanaan Pengabdian Masyarakat

\begin{tabular}{l}
\hline 1. Pelaksanaan pembuatan proposal kegiatan \\
$\downarrow$ \\
\begin{tabular}{|c|}
\hline 2. Permohonan pelaksanaan kegiatan ke ketua Karang Taruna RT. 007 RW. \\
02, Kel. Tanjung Barat, Jagakarsa, Jakarta Selatan
\end{tabular} \\
$\downarrow$ \\
\hline 3. Permohonan penggunaan tempat dalam pelaksanaan kegiatan \\
\hline$\downarrow$ \\
\hline 5. Pelaksanaan kegiatan pelatihan pentingnya penggunaan teori komunikasi \\
verbal dalam berbicara di depan publik. \\
$\downarrow$ \\
\hline 6. Evaluasi pencapaian pelatihan pentingnya bahasa lisan dalam komunikasi \\
\hline
\end{tabular}

Beberapa temuan didapatkan oleh tim abdimas selama kegiatan berlangsung. Pertama, anggota Karang Taruna RT. 007 RW. 02, Kel. Tanjung Barat, Jagakarsa, Jakarta Selatan sebagian sudah mengetahui etika berbicara yang bagus namun kurang dalam berlatih berbicara didepan publik. Kedua, Pemuda yang tergabung dalam Karang Taruna sebagian kecil mengetahui etika berbicara yang baik namun mereka tidak berani berbicara di depan publik. Ketiga, anggota Remaja yang tergabung dalam Karang Taruna sangat antusias dalam mengikuti pelatihan dan berharap ada pelatihan tahap berikutnya.

Berdasarkan temuan selama abdimas bahwa sebagian peserta pelatihan belum memahami etika berbicara lisan di depan umum yang sesuai dengan tuntunan dan kurangnya berlatih dalam berbicara di depan umum. Setelah pelaksanaan abdimas, peserta mengetahui etika komunikasi yang diajarkan dan mempunyai banyak kesempatan berlatih berbicara di depan umum. Sebagian besar peserta berharap kegiatan abdimas dapat dilaksanakan kembali dengan pendalaman pada teknik berbicara di depan umum. Teknik berbicara yang dimaksudkan adalah teknik berbicara di depan umum pada acara keagamaan misalnya, peringatan hari besar Islam, pernikahan, dan lain-lain.

\section{Kesimpulan}

Kegiatan Pengabdian Masyarakat ini memberikan nilai positif pada peserta pelatihan. Ketidaktahuan tentang adanya etika berbicara dalam Islam selama ini dapat dijawab dan ketakutan dalam berbicara di depan umum dapat diminimalisir.

Sebagian besar peserta berharap kegiatan abdimas dapat dilaksanakan kembali dengan pendalaman pada teknik berbicara di depan umum. Teknik berbicara yang dimaksudkan adalah teknik berbicara di depan umum pada acara keagamaan misalnya, peringatan hari besar Islam, pernikahan, dan lain-lain. 


\section{Ucapan Terima Kasih}

Ucapan terima kasih kami ucapkan kepada Ketua RT. 007 RW. 05, Kel. Tanjung Barat, Jagakarsa, Jakarta Selatan atas kesempatan yang diberikan. Ucapan terima kasih juga ditujukan kepada ketua Karang Taruna RT. 007 RW. 05 atas kerjasamanya. Dan, ucapan terima kasih yang sebesar-besarnya kepada dewan redaksi Jurnal JPMM atas kesediaannya dalam membantu proses penerbitan artikel ini.

\section{Referensi}

Baryadi. 2003. Teori Sopan Santun Berbahasa. Yogyakarta: Makalah Pertemuan Ilmiah Bahasa dan Sastra Indonesia XXV.

Dimyati \& Mudjiono. 2013. Belajar dan Pembelajaran. Jakarta: Departemen Pendidikan \& Kebudayaan.

Komala, Lukiati. 2009. IImu Komunikasi Perspektif, Proses, dan Konteks. Bandung: Widya Padjajaran.

Mulyana, Deddy. 2005. Ilmu Komunikasi Suatu Pengantar. Bandung: PT. Remaja Rosdakarya.

William. Gorden. 1978. Communcation: Personal and Public. CA: Alfred. 